\title{
EFFECT OF MYCORRHIZA AND MINERAL FERTILIZATION ON GROWTH AND OIL PRODUCTIVITY OF Foeniculum vulgare, MILL. PLANT UNDER SINAI CONDITIONS
}

(Received: 21.6.2016)

\author{
By \\ M. Y. M. Badawy
}

Medicinal and Aromatic Plants Department, Desert Research Center, El-Matariya, Cairo, Egypt.

\begin{abstract}
The current experiment was conducted at El-Maghara Research Station (North Sinai), Desert Research Center, during the two successive seasons of 2012/2013 and 2013/2014 to study the effect of bio-fertilizer (mycorrhiza) and mineral fertilizers on growth, yield, essential oil and chemical composition of fennel plants to minimize usage of chemical fertilizers. This experiment was split plot design with three replications, the main plots were the mycorrhiza at two levels, non-inoculated and inoculated, and the sub plots were the chemical fertilizers at four levels $(0,50,75$ and $100 \%$ of the recommended dose of NPK). The results showed that, mycorrhiza application led to a significant increase in plant height, number of umbels/plant, fresh and dry weights/plant, fruit weight/plant, fruit yield/feddan and oil yield/feddan. Also, using 75 and $100 \%$ of the recommended dose of NPK achieved a significant increase in the same former characteristics, but, $75 \%$ was the most effective treatment in most cases. Interaction between mycorrhiza and chemical fertilizers had a significant effect on all parameters, where inoculated fennel plants with mycorrhiza plus $75 \%$ of the recommended dose of NPK gave the highest values of vegetative growth parameters, fruit yield/feddan, oil yield/feddan, $\mathrm{N}$ and total carbohydrates percentage. Also, this treatment was marked by a decrease in Estragole content in volatile oil composition, where the major component was Limonene $(34.58 \%)$ followed by Estragole $(29.30 \%)$, Fenchone $(20.43 \%)$, Anethole (3.54 \%), $\gamma$-Terpinene $(1.25 \%)$ and $\alpha$-Pinene $(2.71 \%)$. Fennel plants inoculated with mycorrhiza only without chemical fertilizers gave the highest volatile oil percentage. Meanwhile, the main component was Estragole $(50.65 \%)$, followed by Limonene (18.72\%), Anethole (13.83\%), Fenchone $(4.57 \%)$, $\gamma$-Terpinene $(3.12 \%)$ and $\alpha$-Pinene $(1.61 \%)$.
\end{abstract}

Key words: Mycorrhiza, chemical fertilizers, Foeniculum vulgare, Mill., Anethole, Estragole.

\section{INTRODUCTION}

Fennel (Foeniculum vulgare Mill.) which belongs to Apiaceae family is one of the most important medicinal and aromatic plants due to its estrogenic activities and uses as a carminative, diuretic, anti-inflammatory and antimicrobial. Considering the importance of biological fertilizer for sustainable agriculture and the necessity to minimize chemical fertilizers application in agricultural ecosystems, for the purpose of getting high quality products free of harmful agrochemicals for human safety.

The mutualistic association between roots and mycorrhiza fungi can improve a plant's nutritional state since it facilitates the absorption of the main elements in the soil ( $\mathrm{N}, \mathrm{P}$ and $\mathrm{K})$, increases the volume of soil explored by the root system, improves the plant's resistance to some diseases, and increases its production of dry matter, (Mohsen et al., 2014). The highest seed yield and essential oil yield of fennel were obtained by using mycorrhiza inoculation (Mohammad, 2012). Using two arbuscular mycorrhizal (AM) fungi Glomus macrocarpum and Glomus fasciculatum significantly improved growth and essential oil concentration of Foeniculum vulgare, (Mill). (Kapoor et al. 2004). However, adding the chemical fertilizer (phosphorus) with mycorrhizal inoculants registered up to $78 \%$ increase in essential oil concentration of fennel seeds over nonmycorrhizal control. Kapoor et al. (2004) and Alireza (2012) reported that, inoculation mycorrhiza and phosphate dissolving bacteria with applied NP fertilizers, increased vegetative growth of fennel plants compared to chemical fertilizer treatments only. Paolo and Paulina, (2008) noticed that, both mycorrhiza inoculation 
fertilizer treatments only. Paolo and Paulina, (2008) noticed that, both mycorrhiza inoculation and high fertilization acted in the direction of reducing the symptoms of salinity stress by increasing growth and inflorescence. The simultaneous application of mycorrhiza and high fertilization provided higher tolerance to salinity than one single factor.

Therefore, the present study was conducted to evaluate the effect of bio-fertilizer (mycorrhiza) and chemical fertilizers on growth, yield, essential oil and chemical composition of fennel plants to minimize the usage of chemical fertilizers under Sinai conditions.

\section{MATERIALS AND METHODS}

The present study was carried out during the two successive seasons; 2012/2013 and 2013/2014 at El-Maghara Research Station Desert Research Center, North Sinai Governorate to investigate the effect of biofertilizer (mycorrhiza) and chemical fertilizers on growth, yield of fruits and chemical composition of fennel (Foeniculum vulgare, Mill.) plant.

\subsection{Plant material and procedure}

Seeds of fennel were obtained from ElMaghara Research Station, Desert Research Center, North Sinai Governorate. Seeds were sown in the field on the $25^{\text {th }}$ and the $21^{\text {st }}$ of October 2012 and 2013, respectively at distances of $40 \mathrm{~cm}$ between hills (thinned to one plant/hill) and $75 \mathrm{~cm}$ between rows. Drip irrigation system was applied in the whole experiment using droppers $(4 \mathrm{~L} / \mathrm{h})$ every 3 days (for two hours), using moderate salinity water (2688 ppm).

\section{2-2-Soil and water analysis}

Soil analysis is shown in Table (A). Soil samples representing the experimental area were taken at $0-30 \mathrm{~cm}$ depth. The water analysis samples shown in Table (B) were taken from the irrigation water used from El-Maghara Station.

Organic fertilizer (compost) was added as basic dose for all experiments at the rate of 15 $\mathrm{m}^{3}$ per feddan, the chemical properties of compost are shown in Table (C).

\subsection{Fertilization treatments:}

The fertilization treatments included the following:

\subsubsection{Bio-fertilization treatments:}

2.3.1.1. Without mycorrhiza $\left(\mathrm{M}_{0}\right)$.

2.3.1.2. With mycorrhiza $\left(\mathrm{M}_{1}\right)$.

The bio-fertilizer (Mycorrhiza) was provided from the unit of Bio-fertilizers, Faculty of Agriculture, Ain Shams University, Egypt. The bio-fertilizer ( $1 \mathrm{~L}$ mixtures of 3 strains of mycorrhiza) was added before sowing, by added latex material to seeds, then mixed the seeds with this material, then added mycorrhiza to seeds.

Arbuscular mycorrhiza fungi consisted of a mixture of Glomus etunicatum, Glomus intraradices and Glomus monosporum spores at concentration of $250 \mathrm{spore} / \mathrm{ml}$.

\subsubsection{Chemical fertilization treatment}

2.3.2.1. Control (without chemical fertilizers) $\left(\mathrm{F}_{0}\right)$.

2.3.2.2. $50 \%$ recommended dose of NPK $\left(\mathrm{F}_{1}\right)$.

2.3.2.3. $75 \%$ recommended dose of NPK $\left(\mathrm{F}_{2}\right)$.

2.3.2.4. $100 \%$ recommended dose of NPK $\left(\mathrm{F}_{3}\right)$.

$100 \%$ recommended dosage of NPK $[300 \mathrm{~kg}$ ammonium sulfate $(20.5 \% \mathrm{~N})+200 \mathrm{~kg}$ calcium super phosphate $\left(15.5 \% \mathrm{P}_{2} \mathrm{O}_{5}\right)+100 \mathrm{~kg}$ potassium sulfate $\left.\left(\begin{array}{lll}48 & \% & \mathrm{~K}_{2} \mathrm{O}\end{array}\right)\right]$ according to Badawy, (2002).

Both calcium super phosphate and organic fertilizers were added at 7 days before sowing date. The nitrogen as well as potassium fertilizer were added in three equal doses, the

Table (A): Chemical analysis of the soil.

\begin{tabular}{|c|c|c|c|c|c|c|c|c|c|}
\hline \multirow{2}{*}{ pH } & \multirow{2}{*}{$\begin{array}{c}\text { E.C } \\
\text { mmhos } / \mathbf{c m}\end{array}$} & \multicolumn{4}{|c|}{ Soluble cations $\mathrm{mg} / \mathbf{l}$} & \multicolumn{4}{|c|}{ Soluble anions mg /l } \\
\hline & & $\mathbf{C a}^{++}$ & $\mathrm{Mg}^{++}$ & $\mathrm{Na}^{+}$ & $\mathbf{K}^{+}$ & $\mathrm{CO}_{3}{ }^{--}$ & $\mathrm{HCO}_{3}^{-}$ & $\mathrm{Cl}^{-}$ & $\mathrm{SO}_{4}^{--}$ \\
\hline 7.70 & 2.80 & 114.10 & 36.77 & 440 & 12 & 0 & 34.07 & 728.7 & 340.07 \\
\hline \multicolumn{2}{|c|}{ (TDS), mg/l } & \multicolumn{4}{|c|}{ Total nitrogen $(\%)$} & \multicolumn{4}{|c|}{ Phosphate, mg/L } \\
\hline \multicolumn{2}{|c|}{1792} & \multicolumn{4}{|c|}{0.42} & \multicolumn{4}{|c|}{85.5} \\
\hline
\end{tabular}

Table (B): Water analysis of the irrigation water.

\begin{tabular}{|c|c|c|c|c|c|c|c|c|c|}
\hline \multirow{2}{*}{ pH } & \multirow{2}{*}{$\begin{array}{c}\text { E.C } \\
\text { mmhos } / \mathrm{cm}\end{array}$} & \multicolumn{4}{|c|}{ Soluble cations $\mathrm{mg} / \mathrm{l}$} & \multicolumn{4}{|c|}{ Soluble anions mg/l } \\
\hline & & $\mathrm{Ca}^{++}$ & $\mathrm{Mg}^{++}$ & $\mathrm{Na}^{+}$ & $\mathbf{K}^{+}$ & $\mathrm{CO}_{3}{ }^{--}$ & $\mathrm{HCO}_{3}{ }^{-}$ & $\mathrm{Cl}^{-}$ & $\mathrm{SO}_{4}$ \\
\hline 7.5 & 4.20 & 188.40 & 79.79 & 560 & 66 & 0 & 238.48 & 923.02 & 580 \\
\hline \multicolumn{2}{|c|}{ (TDS), mg/l } & \multicolumn{2}{|c|}{ TOC, $\%$} & \multicolumn{2}{|c|}{ Nitrate,mg/l } & \multicolumn{4}{|c|}{ Phosphate, $\mathrm{mg} / \mathrm{l}$} \\
\hline \multicolumn{2}{|c|}{2688} & \multicolumn{2}{|c|}{ Nil } & \multicolumn{2}{|c|}{ Nil } & \multicolumn{4}{|c|}{ Nil } \\
\hline
\end{tabular}


Table (C): The chemical properties of compost.

\begin{tabular}{|c|c|c|c|c|c|c|c|}
\hline Humidity & Ash & O.M. & O.C & $\mathrm{C} / \mathrm{N}$ & $\mathrm{N}$ & $\mathrm{P}$ & $\mathrm{K}$ \\
\hline $26 \%$ & $9 \%$ & $65 \%$ & $36.1 \%$ & $16: 1$ & $2.15 \%$ & $1.5 \%$ & $1.26 \%$ \\
\hline \multirow[t]{2}{*}{$\mathrm{pH}$} & \multicolumn{4}{|c|}{ Trace elements (ppm) } & & \multirow{2}{*}{\multicolumn{2}{|c|}{$\mathrm{NaCl}$}} \\
\hline & $\mathrm{Fe}^{++}$ & $\mathrm{Mn}^{++}$ & $\mathrm{Cu}^{++}$ & $\mathrm{Zn}^{++}$ & Water capacity & & \\
\hline 5.8 & 1025 & 115 & 180 & 28 & $250 \%$ & & $1 \%$ \\
\hline
\end{tabular}

first one was applied 60 days after sowing (when plant height was $15 \mathrm{~cm}$ approximately) and the second dose was added after 30 days from the first one, while the third dose was added 30 days after the second one.

\subsection{Statistical analysis}

The layout of the experiment was split plot design with three replications, the main plots contain the bio-fertilizers (Mycorrhiza), while the chemical fertilizers were applied in the sub plots. The plants in the two seasons were harvested on the ( $4^{\text {th }}$ of May for the first season and the $6^{\text {th }}$ of May for the second season). The data from this experiment were subjected to the statistical analysis of variance using Mstate Statistical Software. L. S .D. test at 0.05 was used to compare the average means of treatments, carried out according to Snedecor and Cochran (1982).

\subsection{Data recorded}

Data were recorded for the following parameters: plant height, the number of umbles/plant, fresh and dry weights/plant, fruit weight/plant and fruit yield/feddan.

\subsection{Chemical analysis}

2.6.1. Determination of essential oil percentage and GC/Mass analysis of volatile oil

The essential oil percentage in fennel fruit was determined according to the British Pharmacopoeia (1963). The chemical composition of the essential oil was determined using a Thermo Scientific, Trace GC Ultra/ISQ Single Quadrupole MS, TG-5MS fused silica capillary column $(30 \mathrm{~m}, 0.251 \mathrm{~mm}, 0.1 \mathrm{~mm}$ film thickness). The quantification of all the identified components was investigated using a percent relative peak area. A tentative identification of the compounds was performed based on the comparison of their relative retention time and mass spectra with those of the NIST, WILLY library data of the GC/MS system according to Adams, (2007).

\subsubsection{Determination of Nitrogen, Phosphorus, Potassium and total carbohydrates}

Elements contents were determined in the acid digested solution, which was prepared according to Hach et. al., (1985). Nitrogen content was determined by modified microKjeldahl method as described by A. O. A. C. (1970). Phosphorus was estimated according to Snell and Snell (1949). Potassium was estimated using flame photometer method according to Chapman and Pratt (1961). Total carbohydrate percentages in the fruits were determined according to Chaplin and Kennedy (1994).

\section{RESULTS AND DISCUSSION \\ 3.1. Vegetative growth \\ 3.1.1. Plant height}

Data in Table (1) showed that, in both seasons, using inoculation with mycorrhiza led to a significant increase in plant height. The highest values were 97.54 and $109.58 \mathrm{~cm}$ in the

Table (1): Effect of bio-fertilizer (mycorrhiza) and chemical fertilizers on plant height of fennel (Foeniculum vulgare, Mill.) plants, during 2012/2013 and 2013/2014 seasons

\begin{tabular}{|c|c|c|c|c|c|c|}
\hline \multirow{3}{*}{ Treatments } & \multicolumn{6}{|c|}{ Plant height $(\mathbf{c m})$} \\
\hline & \multicolumn{3}{|c|}{ First season, 2012} & \multicolumn{3}{|c|}{$\begin{array}{l}\text { Second season, } 2013 \\
\end{array}$} \\
\hline & $\mathbf{M}_{0}$ & $\mathbf{M}_{1}$ & Mean & $\mathbf{M}_{0}$ & $M_{1}$ & Mean \\
\hline $\mathbf{F}_{0}$ & 77.70 & 92.89 & 85.30 & 88.56 & 102.0 & 95.28 \\
\hline $\mathbf{F}_{1}$ & 81.53 & 98.17 & 89.85 & 96.00 & 105.3 & 100.65 \\
\hline $\mathbf{F}_{2}$ & 93.21 & 98.30 & 95.76 & 98.55 & 114.40 & 106.48 \\
\hline $\mathbf{F}_{3}$ & 88.97 & 100.80 & 94.89 & 94.89 & 116.60 & 105.75 \\
\hline Mean & 85.35 & 97.54 & & 94.50 & 109.58 & \\
\hline \multicolumn{7}{|l|}{ L.S.D at 0.05} \\
\hline M & \multicolumn{3}{|l|}{2.29} & \multicolumn{3}{|l|}{8.57} \\
\hline $\mathbf{F}$ & \multicolumn{3}{|l|}{3.48} & \multicolumn{3}{|l|}{5.70} \\
\hline $\mathbf{M} \times \mathbf{F}$ & \multicolumn{3}{|l|}{4.93} & \multicolumn{3}{|l|}{8.07} \\
\hline
\end{tabular}

$\mathrm{F}_{0}, \mathrm{~F}_{1}, \mathrm{~F}_{2}$ and $\mathrm{F}_{3}=$ chemical fertilizer at $0,50,75$ and $100 \%$ from R.D.

$\mathrm{M}_{0}=$ without mycorrhiza $\quad \mathrm{M}_{1}=$ with mycorrhiza 
first and second seasons, respectively, with inoculated plants compared to 85.35 and 94.50 $\mathrm{cm}$ in the first and second seasons, respectively for non-inoculated plants.

Concerning the chemical fertilizer treatments, in the first season, the highest plants were from $F_{2}$ followed by $F_{3}$ without significant differences between them, but the difference between these levels and the control $\left(\mathrm{F}_{0}\right)$ were significant. Similar trend was observed in the second season.

Interactions between mycorrhiza and the chemical fertilizers, had a significant effect, where the tallest plants were 100.80 followed by $98.30 \mathrm{~cm}$ in the first season and 116.60 followed by $114.40 \mathrm{~cm}$ in the second season) obtained by using $\mathrm{M}_{1} \mathrm{~F}_{3}$ and $\mathrm{M}_{1} \mathrm{~F}_{2}$, respectively, without significant difference between them, but the difference between these treatments and others were significant. The shortest plants were obtained due to $\mathrm{M}_{0} \mathrm{~F}_{0}$ treatment, giving 77.70 and $88.56 \mathrm{~cm}$ in the first and the second seasons, respectively.

\subsubsection{Number of umbels/plant}

Data in Table (2) showed that, using inoculation with mycorrhiza led to a significant increase in the number of umbels/plant, where the greatest numbers of umbels were 47.05 and 56.36 umbels/plant in the first and second seasons, respectively, with inoculated plants compared to 36.72 and 38.25 in the first and the second season, respectively for non-inoculated plants.

Regarding the chemical fertilizer treatments, in the first season, the highest number of umbels/plant resulted from the $\mathrm{F}_{2}$ and $\mathrm{F}_{3}$ without significant difference between them, but the differences between these levels and the control $\left(\mathrm{F}_{0}\right)$ were significant. However, in the second season, there were non-significant differences between $F_{1}, F_{2}$ and $F_{3}$, but there was a significant increment in the number of umbels/plant compared with control plants $\left(\mathrm{F}_{0}\right)$.

Interactions between mycorrhiza and chemical fertilizers resulted in a significant effect on the number of umbels/plant in most treatments. The greatest number of umbels/plant (48.20 and 68.00 in the first and second season, respectively) were obtained by using $\mathrm{M}_{1} \mathrm{~F}_{3}$ (inoculation with mycorrhiza plus $100 \%$ of chemical fertilizers) and $\mathrm{M}_{1} \mathrm{~F}_{2}$ (inoculation with mycorrhiza plus $75 \%$ of chemical fertilizers), respectively.

\subsubsection{Fresh weight/plant}

Data in Table (3) showed that, the inoculated fennel plants with mycorrhiza led to a significant increase in fresh weight/plant compared with non-inoculated plant in both seasons (379.58 and $519.05 \mathrm{~g} / \mathrm{plant}$ in the first season and 353.60 and $493.63 \mathrm{~g} / \mathrm{plant}$ in the second season, for noninoculated and inoculated, respectively).

Using chemical fertilizer, in both seasons, the highest values of fresh weight/plants resulted from $F_{2}$ and $F_{3}$ without significant difference between them, but the difference between these levels and $F_{0}$ or $F_{1}$ were significant.

Interactions between mycorrhiza and chemical fertilizers caused a significant increment in fresh weight/plant, the heaviest values 628.70 and $579.60 \mathrm{~g} / \mathrm{plant}$ (first and second seasons, respectively) resulted from $\mathrm{M}_{1} \mathrm{~F}_{3}$ (inoculation with mycorrhiza plus $100 \%$ of chemical fertilizers).

\subsubsection{Dry weight/plant}

Data in Table (4) indicated that, inoculated fennel plants with mycorrhiza led to a significant increase in dry weight/plant compared with noninoculated plant in both seasons (138.36 and $183.73 \mathrm{~g} /$ plant in the first season and 181.18 and

Table (2): Effect of bio-fertilizer (mycorrhiza) and chemical fertilizers on the number of umbels/plant of fennel (Foeniculum vulgare, Mill) plants, during 2012/2013 and 2013/2014 seasons

\begin{tabular}{|c|c|c|c|c|c|c|}
\hline \multirow{3}{*}{ Treatments } & \multicolumn{6}{|c|}{ Number of umbels/Plant } \\
\hline & \multicolumn{3}{|c|}{ First season, 2012} & \multicolumn{3}{|c|}{ Second season, 2013} \\
\hline & $\mathbf{M}_{0}$ & $\mathbf{M}_{1}$ & Mean & $\mathbf{M}_{\mathbf{0}}$ & $\mathbf{M}_{1}$ & Mean \\
\hline $\mathbf{F}_{\mathbf{0}}$ & 30.60 & 47.40 & 39.00 & 31.49 & 45.67 & 38.58 \\
\hline $\mathbf{F}_{1}$ & 33.50 & 45.30 & 39.40 & 48.01 & 51.50 & 49.76 \\
\hline $\mathbf{F}_{2}$ & 40.50 & 47.30 & 43.90 & 33.00 & 68.00 & 50.50 \\
\hline $\mathbf{F}_{3}$ & 42.27 & 48.20 & 45.24 & 40.51 & 60.25 & 50.38 \\
\hline Mean & 36.72 & 47.05 & & 38.25 & 56.36 & \\
\hline \multicolumn{7}{|l|}{ L.S.D at 0.05} \\
\hline $\mathbf{M}$ & 3.40 & & & 5.70 & & \\
\hline $\mathbf{F}$ & 1.92 & & & 3.02 & & \\
\hline $\mathbf{M} \times \mathbf{F}$ & 2.72 & & & 4.27 & & \\
\hline
\end{tabular}

$\mathrm{F}_{0}, \mathrm{~F}_{1}, \mathrm{~F}_{2}$ and $\mathrm{F}_{3}=$ chemical fertilizer at $0,50,75$ and $100 \%$ from R.D.

$\mathrm{M}_{0}=$ without mycorrhiza $\quad \mathrm{M}_{1}=$ with mycorrhiza 
Table (3): Effect of bio-fertilizer (mycorrhiza) and chemical fertilizers on the fresh weight (g.)/plant of fennel (Foeniculum vulgare, Mill.) plants, during 2012/2013 and 2013/2014 seasons

\begin{tabular}{|c|c|c|c|c|c|c|}
\hline \multirow{3}{*}{ Treatments } & \multicolumn{6}{|c|}{ Fresh weight/plant (g) } \\
\hline & \multicolumn{3}{|c|}{ First season, 2012} & \multicolumn{3}{|c|}{ Second season, 2013} \\
\hline & $\mathbf{M}_{0}$ & $\mathbf{M}_{1}$ & Mean & $\mathbf{M}_{0}$ & $\mathbf{M}_{1}$ & Mean \\
\hline $\mathbf{F}_{\mathbf{0}}$ & 169.10 & 376.90 & 273.00 & 198.50 & 406.70 & 302.60 \\
\hline $\mathbf{F}_{1}$ & 418.40 & 488.70 & 453.55 & 364.20 & 464.10 & 414.15 \\
\hline $\mathbf{F}_{2}$ & 500.50 & 581.90 & 541.20 & 421.70 & 524.10 & 472.90 \\
\hline $\mathbf{F}_{3}$ & 430.30 & 628.70 & 529.50 & 430.00 & 579.60 & 504.80 \\
\hline Mean & 379.58 & 519.05 & & 353.60 & 493.63 & \\
\hline \multicolumn{7}{|l|}{ L.S.D at 0.05} \\
\hline $\mathbf{M}$ & 60.45 & & & 24.57 & & \\
\hline $\mathbf{F}$ & 71.31 & & & 33.64 & & \\
\hline $\mathbf{M} \times \mathbf{F}$ & 100.80 & & & 47.57 & & \\
\hline
\end{tabular}

$\mathrm{F}_{0}, \mathrm{~F}_{1}, \mathrm{~F}_{2}$ and $\mathrm{F}_{3}=$ chemical fertilizer at $0,50,75$ and $100 \%$ from R.D.

$\mathrm{M}_{0}=$ without mycorrhiza $\quad \mathrm{M}_{1}=$ with mycorrhiza

Table (4): Effect of bio-fertilizer (mycorrhiza) and chemical fertilizers on the dry weight/plant of fennel (Foeniculum vulgare, Mill.) plants, during 2012/2013 and 2013/2014 seasons

\begin{tabular}{|c|c|c|c|c|c|c|}
\hline \multirow{3}{*}{ Treatments } & \multicolumn{6}{|c|}{ Dry weight (g) } \\
\hline & \multicolumn{3}{|c|}{ First season, 2012} & \multicolumn{3}{|c|}{ Second season, 2013} \\
\hline & $\mathbf{M}_{0}$ & $\mathbf{M}_{1}$ & Mean & $\mathbf{M}_{0}$ & $\mathbf{M}_{1}$ & Mean \\
\hline $\mathbf{F}_{\mathbf{0}}$ & 83.33 & 128.00 & 105.67 & 137.40 & 148.90 & 143.15 \\
\hline $\mathbf{F}_{1}$ & 146.90 & 170.60 & 158.75 & 188.90 & 196.70 & 192.80 \\
\hline $\mathbf{F}_{2}$ & 163.60 & 214.00 & 188.80 & 191.70 & 210.00 & 200.85 \\
\hline $\mathbf{F}_{3}$ & 159.60 & 222.30 & 190.95 & 206.70 & 256.10 & 231.40 \\
\hline Mean & 138.36 & 183.73 & & 181.18 & 202.93 & \\
\hline \multicolumn{7}{|l|}{ L.S.D at 0.05} \\
\hline $\mathbf{M}$ & 28.13 & & & 21.00 & & \\
\hline $\mathbf{F}$ & 14.07 & & & 29.07 & & \\
\hline $\mathbf{M} \times \mathbf{F}$ & 19.89 & & & 41.11 & & \\
\hline
\end{tabular}

$\mathrm{F}_{0}, \mathrm{~F}_{1}, \mathrm{~F}_{2}$ and $\mathrm{F}_{3}=$ chemical fertilizer at $0,50,75$ and $100 \%$ from R.D.

$\mathrm{M}_{0}=$ without mycorrhiza $\quad \mathrm{M}_{1}=$ with mycorrhiza

$202.93 \mathrm{~g} /$ plant in the second season, for noninoculated and inoculated, respectively).

In the first season, the heaviest dry weight/plant resulted from applying the $100 \%$ of chemical fertilizers $\left(\mathrm{F}_{3}\right)$ to fennel plants, but without significant difference between this level and $\left(\mathrm{F}_{2}\right)$. However, in the second season, using $\mathrm{F}_{3}$ led to a significant increase in dry weight/plant compared with other levels of chemical fertilizers.

Meanwhile, in the first season, the interactions between mycorrhiza and chemical fertilizers, led to the heaviest dry weight/plant $(222.30$ and $214.00 \mathrm{~g} /$ plant $)$ with the treatments $\mathrm{M}_{1} \mathrm{~F}_{3}$ and $\mathrm{M}_{1} \mathrm{~F}_{2}$, respectively), without significant difference between them. But, the differences between these treatments and others were significant. However, in the second season, the highest value $(256.10 \mathrm{~g} /$ plant $)$ was obtained from the plants received $\mathrm{M}_{1} \mathrm{~F}_{3}$ with significant difference between this treatment and others.

\subsubsection{Fruit weight/plant and fruit yield/feddan}

The results in Tables (5 and 6) clearly indicated that, inoculated fennel plants with mycorrhiza led to a significant increase in fruit weight/plant and fruit yield/feddan compared with non-inoculated in both seasons $(60.73$ and $71.08 \mathrm{~g} / \mathrm{plant}$ and 847.25 and $991.80 \mathrm{~kg} / \mathrm{feddan}$ in the first season and 62.39 and $77.58 \mathrm{~g} / \mathrm{plant}$ and 870.30 and $1082.38 \mathrm{~kg} / \mathrm{feddan}$ in the second one, for non-inoculated and inoculated plants, respectively).

Concerning the chemical fertilizers, the heaviest fruit weight/plant and fruit yield/feddan were obtained with $F_{2}$ and $F_{3}$ without significant difference between them. But, the differences between these levels and others were significant.

In both seasons, the heaviest fruit 
Table (5): Effect of bio-fertilizer (mycorrhiza) and chemical fertilizers on fruit weight/plant of fennel (Foeniculum vulgare, Mill.) plants, during 2012/2013 and 2013/2014 seasons

\begin{tabular}{|c|c|c|c|c|c|c|}
\hline \multirow{3}{*}{ Treatments } & \multicolumn{6}{|c|}{ Fruit weight/plant (g) } \\
\hline & \multicolumn{3}{|c|}{ First season,2012 } & \multicolumn{3}{|c|}{ Second season, 2013} \\
\hline & $\mathbf{M}_{0}$ & $\mathbf{M}_{1}$ & Mean & $\mathbf{M}_{\mathbf{0}}$ & $\mathbf{M}_{1}$ & Mean \\
\hline $\mathbf{F}_{\mathbf{0}}$ & 40.40 & 58.80 & 49.60 & 41.52 & 57.44 & 49.48 \\
\hline $\mathbf{F}_{1}$ & 66.33 & 64.87 & 65.60 & 64.34 & 71.06 & 67.70 \\
\hline $\mathbf{F}_{2}$ & 67.53 & 83.13 & 75.33 & 70.71 & 96.84 & 83.78 \\
\hline $\mathbf{F}_{3}$ & 68.67 & 77.53 & 73.10 & 73.00 & 85.00 & 79.00 \\
\hline Mean & 60.73 & 71.08 & & 62.39 & 77.58 & \\
\hline \multicolumn{7}{|l|}{ L.S.D at 0.05} \\
\hline M & 9.43 & & & 11.09 & & \\
\hline $\mathbf{F}$ & 6.87 & & & 14.78 & & \\
\hline $\mathbf{M} \times \mathbf{F}$ & 9.72 & & & 20.90 & & \\
\hline
\end{tabular}

$\mathrm{F}_{0}, \mathrm{~F}_{1}, \mathrm{~F}_{2}$ and $\mathrm{F}_{3}=$ chemical fertilizer at $0,50,75$ and $100 \%$ from R.D.

$\mathrm{M}_{0}=$ without mycorrhiza $\quad \mathrm{M}_{1}=$ with mycorrhiza

Table (6): Effect of bio-fertilizer (mycorrhiza) and chemical fertilizers on fruit yield/feddan of fennel (Foeniculum vulgare, Mill.) plants, during 2012/2013 and 2013/2014 seasons

\begin{tabular}{|c|c|c|c|c|c|c|}
\hline \multirow{3}{*}{ Treatments } & \multicolumn{6}{|c|}{ Fruit yield/feddan (kg) } \\
\hline & \multicolumn{3}{|c|}{ First season, 2012} & \multicolumn{3}{|c|}{ Second season, 2013} \\
\hline & $\mathbf{M}_{0}$ & $\mathbf{M}_{1}$ & Mean & $\mathbf{M}_{0}$ & $\mathbf{M}_{1}$ & Mean \\
\hline $\mathbf{F}_{\mathbf{0}}$ & 563.60 & 820.30 & 691.95 & 579.20 & 801.30 & 690.25 \\
\hline $\mathbf{F}_{1}$ & 925.40 & 904.90 & 915.15 & 897.60 & 991.20 & 944.40 \\
\hline $\mathbf{F}_{2}$ & 942.10 & 1160.00 & 1051.05 & 986.40 & 1351.00 & 1168.70 \\
\hline $\mathbf{F}_{3}$ & 957.90 & 1082.00 & 1019.95 & 1018.00 & 1186.00 & 1102.00 \\
\hline Mean & 847.25 & 991.80 & & 870.30 & 1082.38 & \\
\hline \multicolumn{7}{|l|}{ L.S.D at 0.05} \\
\hline M & 131.6 & & & 154.7 & & \\
\hline $\mathbf{F}$ & 95.90 & & & 206.2 & & \\
\hline $\mathbf{M} \times \mathbf{F}$ & 135.6 & & & 291.6 & & \\
\hline
\end{tabular}

$\mathrm{F}_{0}, \mathrm{~F}_{1}, \mathrm{~F}_{2}$ and $\mathrm{F}_{3}=$ chemical fertilizer at $0,50,75$ and $100 \%$ from R.D.

$\mathrm{M}_{0}=$ without mycorrhiza $\quad \mathrm{M}_{1}=$ with mycorrhiza

weight/plant and fruit yield/feddan $(83.13$ and $77.53 \mathrm{~g} / \mathrm{plant}$ and 1160.0 and $1082.0 \mathrm{~kg} / \mathrm{feddan}$ in the first season and 96.84 and $85.00 \mathrm{~g} / \mathrm{plant}$ and 1351.0 and $1186.0 \mathrm{~kg} /$ feddan in the second season, respectively) resulted from $\mathrm{M}_{1} \mathrm{~F}_{2}$ followed by $\mathrm{M}_{1} \mathrm{~F}_{3}$, respectively, without significant difference between them. While, comparing them with other treatments showed a significant increment in fruit weight/plant and fruit yield/feddan.

Generally, the conclusion of the obtained results is that, the treatments $\mathrm{M}_{1} \mathrm{~F}_{2}$ (treating the plants by mycorrhiza $+75 \%$ of chemical fertilizers) gave the highest fruit weight/plant and fruit yield/feddan. Thus, we recommend this treatment for the highest fruit weight/plant and fruit yield/feddan.

Symbiosis of mycorrhiza with plants stimulates degradation of soil organic materials. Mycorrhiza by different mechanisms such as production of indole acetic acid, increase plant resistance to different stresses such as water salinity. Also it can cause on increase in plant growth (plant height, number of umbels/plant, fresh and dry weights/plant, fruit weight/plant and fruit yield/feddan), which led to reducing the amount of chemical fertilizer. These results are in accordance with the observations of earlier researchers Mohammad (2012) with fennel, who reported that, the highest seed yield was obtained with mycorrhiza application. Fatemeh et al. (2013) on dill plant, mentioned that, mycorrhiza application increased seed yield nearly $32.5 \%$ more than the control treatment. Karagiannidis et al. (2011) on oregano and mint plants, suggested that, the use of mycorrhizal fungi may allow plant growth in low fertility soils and reduce fertilizer inputs. Kapoor et al. (2004) on fennel plant, reported that, AM inoculation of plants with phosphorus fertilization significantly enhanced plant growth compared to either of the components applied 
separately. Darzi et al., (2007) on fennel plant, showed that, the highest plant height, umbels number/plant, 1000-seed weight, biological yield and seed yield were obtained through mycorrhiza inoculation.

\subsection{Volatile oil}

\subsubsection{Oil percentage}

From the data shown in Table (7) it may be remarked that, mycorrhiza had not a significant effect on volatile oil percentages in both seasons.

Concerning the chemical fertilizers, in the first season, the highest volatile oil percentages resulted from the control $\left(\mathrm{F}_{0}\right)$ and $\mathrm{F}_{3}$, without significant differences between all levels of chemical fertilizers. Meanwhile, in the second season, the highest volatile oil percentages obtained from the control $\left(\mathrm{F}_{0}\right)$ with significant differences between this level and other levels, clearly indicated that, applied and increase the level of chemical fertilizers led to a decrease in volatile oil percentages.

Regarding the interactions between mycorrhiza and chemical fertilizers, in both seasons, the highest volatile oil percentages (1.32 and $1.46 \%$ in the first and second seasons, respectively) were obtained from $\mathrm{M}_{1} \mathrm{~F}_{0}$ which showed that, in the case of inoculated fennel plants with mycorrhiza only without applied any chemical fertilizers gave the highest volatile oil percentages. This treatment gave the highest volatile oil percentages.

The present results are in agreement with the observations of researchers such as Karagiannidis et al. (2011) who found that, mycorrhizal oregano and mint plants had a higher content of essential oils than nonmycorrhizal plants.

\subsubsection{Oil yield/feddan}

Data presented in Table (8) showed that, inoculated fennel plants with mycorrhiza led to a significant increase in oil yield/feddan compared with non-inoculated in the first season, and in the second season, but, without a significant difference.

As far as the chemical fertilizers, in the first season, the highest oil yield/feddan resulted from $\mathrm{F}_{3}$ and $\mathrm{F}_{2} \quad(12.56$ and 11.42 L/feddan, respectively), without significant difference between them. But, the differences between these levels and others were significant. However, in the second season there wewre no significant differences between $F_{1}, F_{2}$ and $F_{3}$ but, there was an increment in oil yield/feddan compared with other levels and the control $\left(\mathrm{F}_{0}\right)$.
Interactions between mycorrhiza and chemical fertilizers, in both seasons produced, the highest oil yield/feddan (15.31 and 13.90 1/feddan in the first season and 15.53 and 12.98 $1 /$ feddan in the second season were obtained from $\mathrm{M}_{1} \mathrm{~F}_{2}$ and $\mathrm{M}_{1} \mathrm{~F}_{3}$, respectively without significant difference between them.

Generally, the treatment $\mathrm{M}_{1} \mathrm{~F}_{2}$ (inoculated fennel plants with mycorrhiza $+75 \%$ of chemical fertilizers) gave the highest oil yield/feddan. Thus we recommend this treatment for the highest oil yield/feddan. The increase in oil yield/feddan due to the increase in fruit yield/feddan and the volatile oil percentages.

The observed results were supported by several investigators such as Mohammad (2012) on fennel plants who reported that, the highest essential oil yield was obtained with mycorrhiza application. Karagiannidis et al. (2011) on oregano and mint plants, suggested that the use of mycorrhiza fungi may allow plant growth in low fertility soils, reduce fertilizer inputs and increase the production of essential oil.

\subsection{Chemical composition}

\subsubsection{Nitrogen, phosphorus, potassium and total carbohydrates content}

Data in Table (9) indicated that, the increase in the amount of chemical fertilizers from 0 to $75 \%$ resulted in an increment in nitrogen content especially with using mycorrhiza. Also, in most cases, using mycorrhiza led to an increase in nitrogen content compared with the non treated plants. The same trend was observed with potassium content, but did not show any impact of mycorrhiza.

Concerning phosphorus content, inoculated fennel plants with mycorrhiza with the first and second levels of chemical fertilizers ( 0 and 50 $\%)$ led to increase phosphorus content compared with the non-inoculated by mycorrhiza. Kapoor et al. (2004) on fennel, reported that, AM inoculation of plants with phosphorus fertilization significantly enhanced P-uptake compared to either of the components applied separately.

The decrease in phosphorus content in inoculated fennel plants with the high levels of chemical fertilizers may be due to the decrease in growth of mycorrhiza in these conditions. This trend was confirmed by Paolo and Paulina, (2008) who showed that, the rate of root colonization by the mycorrhiza was significantly reduced by both saline irrigation and high fertilization. 
Table (7): Effect of bio-fertilizer (mycorrhiza) and chemical fertilizers on oil percentage of fennel (Foeniculum vulgare, Mill.) fruits, during 2012/2013 and 2013/2014 seasons

\begin{tabular}{|c|c|c|c|c|c|c|}
\hline \multirow{3}{*}{ Treatments } & \multicolumn{6}{|c|}{ Volatile oil percentage (\%) } \\
\hline & \multicolumn{3}{|c|}{ First season, 2012} & \multicolumn{3}{|c|}{ Second season, 2013} \\
\hline & $\mathbf{M}_{0}$ & $\mathbf{M}_{1}$ & Mean & $\mathbf{M}_{0}$ & $\mathbf{M}_{1}$ & Mean \\
\hline $\mathbf{F}_{\mathbf{0}}$ & 1.12 & 1.32 & 1.22 & 1.35 & 1.46 & 1.40 \\
\hline $\mathbf{F}_{1}$ & 1.30 & 0.80 & 1.05 & 1.36 & 1.10 & 1.23 \\
\hline $\mathbf{F}_{2}$ & 0.80 & 1.32 & 1.06 & 1.15 & 1.15 & 1.15 \\
\hline $\mathbf{F}_{3}$ & 1.17 & 1.28 & 1.22 & 0.95 & 1.10 & 1.02 \\
\hline Mean & 1.10 & 1.18 & & 1.20 & 1.20 & \\
\hline \multicolumn{7}{|l|}{ L.S.D at 0.05} \\
\hline M & N.S. & & & N.S. & & \\
\hline $\mathbf{F}$ & N.S. & & & 0.08 & & \\
\hline $\mathbf{M} \times \mathbf{F}$ & 0.37 & & & 0.12 & & \\
\hline
\end{tabular}

$\mathrm{F}_{0}, \mathrm{~F}_{1}, \mathrm{~F}_{2}$ and $\mathrm{F}_{3}=$ chemical fertilizer at $0,50,75$ and $100 \%$ from R.D.

$\mathrm{M}_{0}=$ without mycorrhiza $\quad \mathrm{M}_{1}=$ with mycorrhiza

Table (8): Effect of bio-fertilizer (mycorrhiza) and chemical fertilizers on oil yield/feddan of fennel (Foeniculum vulgare, Mill.) plants, during 2012/2013 and 2013/2014 seasons

\begin{tabular}{|c|c|c|c|c|c|c|}
\hline \multirow{3}{*}{ Treatments } & \multicolumn{6}{|c|}{ Oil yield/feddan $(\mathrm{L})$} \\
\hline & \multicolumn{3}{|c|}{ First season, 2012} & \multicolumn{3}{|c|}{ Second season, 2013} \\
\hline & $\mathbf{M}_{0}$ & $\mathbf{M}_{1}$ & Mean & $\mathbf{M}_{\mathbf{0}}$ & $\mathbf{M}_{1}$ & Mean \\
\hline $\mathbf{F}_{\mathbf{0}}$ & 6.31 & 10.83 & 8.57 & 7.81 & 11.72 & 9.76 \\
\hline $\mathbf{F}_{1}$ & 12.07 & 7.24 & 9.65 & 12.28 & 10.97 & 11.63 \\
\hline $\mathbf{F}_{2}$ & 7.53 & 15.31 & 11.42 & 11.44 & 15.53 & 13.48 \\
\hline $\mathbf{F}_{3}$ & 11.23 & 13.90 & 12.56 & 9.72 & 12.98 & 11.35 \\
\hline Mean & 9.28 & 11.82 & & 10.31 & 12.80 & \\
\hline \multicolumn{7}{|l|}{ L.S.D at 0.05} \\
\hline M & 2.21 & & & N.S. & & \\
\hline $\mathbf{F}$ & 2.88 & & & 2.25 & & \\
\hline $\mathbf{M} \times \mathbf{F}$ & 4.08 & & & 3.18 & & \\
\hline
\end{tabular}

$\mathrm{F}_{0}, \mathrm{~F}_{1}, \mathrm{~F}_{2}$ and $\mathrm{F}_{3}=$ chemical fertilizer at $0,50,75$ and $100 \%$ from R.D.

$\mathrm{M}_{0}=$ without mycorrhiza $\quad \mathrm{M}_{1}=$ with mycorrhiza

Table (9): Effect of bio-fertilizer (mycorrhiza) and chemical fertilizers on N, P, K and total carbohydrates content of fruit fennel (Foeniculum vulgare, Mill.) plants, during 2012/2013 and 2013/2014 seasons.

\begin{tabular}{|c|c|c|c|c|c|c|c|c|c|}
\hline \multirow{2}{*}{ Treatments } & \multicolumn{2}{|c|}{$\mathbf{N} \%$} & \multicolumn{2}{c|}{$\mathbf{P} \%$} & \multicolumn{2}{c|}{ K \% } & \multicolumn{2}{c|}{ Total carbohydrates \% } \\
\cline { 2 - 10 } & $\begin{array}{c}\text { First } \\
\text { season }\end{array}$ & $\begin{array}{c}\text { Second } \\
\text { season }\end{array}$ & $\begin{array}{c}\text { First } \\
\text { season }\end{array}$ & $\begin{array}{c}\text { Second } \\
\text { season }\end{array}$ & $\begin{array}{c}\text { First } \\
\text { season }\end{array}$ & $\begin{array}{c}\text { Second } \\
\text { season }\end{array}$ & $\begin{array}{c}\text { First } \\
\text { season }\end{array}$ & $\begin{array}{c}\text { Second } \\
\text { season }\end{array}$ \\
\hline $\mathbf{M}_{\mathbf{0}}$ & $\mathbf{F}_{\mathbf{0}}$ & 0.69 & 1.27 & 0.27 & 0.30 & 0.99 & 0.96 & 13.20 & 12.21 \\
\hline $\mathbf{M}_{\mathbf{0}}$ & $\mathbf{F}_{\mathbf{1}}$ & 2.92 & 1.37 & 0.37 & 0.45 & 1.10 & 1.10 & 19.58 & 18.16 \\
\hline $\mathbf{M}_{\mathbf{0}}$ & $\mathbf{F}_{\mathbf{2}}$ & 1.03 & 2.40 & 0.57 & 0.53 & 1.14 & 1.38 & 24.35 & 30.26 \\
\hline $\mathbf{M}_{\mathbf{0}}$ & $\mathbf{F}_{\mathbf{3}}$ & 1.03 & 1.37 & 0.50 & 0.39 & 1.14 & 1.14 & 19.57 & 34.29 \\
\hline & & & & & & & & & \\
\hline $\mathbf{M}_{\mathbf{1}}$ & $\mathbf{F}_{\mathbf{0}}$ & 2.40 & 1.37 & 0.46 & 0.45 & 0.99 & 1.00 & 18.90 & 21.40 \\
\hline $\mathbf{M}_{\mathbf{1}}$ & $\mathbf{F}_{\mathbf{1}}$ & 3.43 & 1.54 & 0.49 & 0.46 & 1.03 & 1.07 & 32.40 & 32.49 \\
\hline $\mathbf{M}_{\mathbf{1}}$ & $\mathbf{F}_{\mathbf{2}}$ & 3.50 & 2.60 & 0.43 & 0.38 & 1.07 & 1.17 & 38.69 & 37.82 \\
\hline $\mathbf{M}_{\mathbf{1}}$ & $\mathbf{F}_{\mathbf{3}}$ & 1.72 & 1.72 & 0.38 & 0.39 & 1.10 & 1.14 & 33.82 & 35.29 \\
\hline
\end{tabular}

$\mathrm{F}_{0}, \mathrm{~F}_{1}, \mathrm{~F}_{2}$ and $\mathrm{F}_{3}=$ chemical fertilizer at $0,50,75$ and $100 \%$ from R.D.

$\mathrm{M}_{0}=$ without mycorrhiza $\quad \mathrm{M}_{1}=$ with mycorrhiza

As far as the total carbohydrates content, there was a match results with the results obtained on the nitrogen content.

Generally, treated fennel plants with $\mathrm{M}_{1} \mathrm{~F}_{2}$ led to the highest content of nitrogen and total carbohydrates. But, the highest of phosphorus and potassium content resulted from $\mathrm{M}_{0} \mathrm{~F}_{2}$.

These results of increasing the content of nitrogen, phosphorus and total carbohydrates content in inoculated fennel plants may be due to 
raising the absorption of the nutrients from the soil by the association of mycorrhiza with the roots of fennel, which are involved in the absorption of nutrients from the area around the roots.

These results are in harmony with several researchers such as Mohsen et al. (2014) who reported that, the mutualistic association between roots and mycorrhizal fungi can improve a plant's nutritional state since it facilitates the absorption of the main elements in the soil $(\mathrm{N}, \mathrm{P}$ and $\mathrm{K})$, increases the volume of soil explored by the root system, improves the plant's resistance to some diseases and increases its production of dry matter. Karagiannidis et al. (2011) found that mycorrhizal oregano and mint plants had a higher content of nutrient elements than non-mycorrhizal plants.

\subsubsection{Analysis of Fennel volatile oil components by GC-MS}

Selected three volatile oil samples to discretion of the components, it is a representing the highest volatile oil percentages $\left(\mathrm{M}_{1} \mathrm{~F}_{0}\right)$, the highest oil yield/feddan $\left(\mathrm{M}_{1} \mathrm{~F}_{2}\right)$ and the control plants $\left(\mathrm{M}_{0} \mathrm{~F}_{0}\right)$. The samples of the essential oil during the second season were subjected to (GCMS) analysis. The main compounds are shown in Table (10). Thirdly two compounds were

Table (10): Chemical composition of the essential oils of three treatments using GC-MS:

\begin{tabular}{|c|c|c|c|c|}
\hline No & Compound name & $\mathbf{M}_{0} \mathbf{F}_{0}$ & $\mathbf{M}_{1} \mathbf{F}_{0}$ & $\mathbf{M}_{1} \mathbf{F}_{2}$ \\
\hline 1 & $\alpha$-Pinene, $(-)-$ & 1.24 & 1.61 & 2.71 \\
\hline 2 & 3-Carene & 0.07 & 0.08 & 0.15 \\
\hline 3 & Sabinene & 0.94 & 0.93 & 1.08 \\
\hline 4 & $\alpha$-Myrcene & 0.41 & 0.36 & 0.64 \\
\hline 5 & $\alpha$-Phellandrene & 0.16 & 0.38 & 1.29 \\
\hline 6 & P-Cymene & 1.12 & 0.50 & 0.13 \\
\hline 7 & D-Limonene & 14.55 & 18.72 & 34.58 \\
\hline 8 & b-Ocimene, $(\mathrm{E})$ & 0.12 & 0.17 & 0.26 \\
\hline 9 & $\gamma$-Terpinene & 4.21 & 3.12 & 1.25 \\
\hline 10 & L-Fenchone & 11.83 & 4.57 & 20.43 \\
\hline 11 & trans-p-Mentha-2,8-dienol & 0.14 & 0.10 & - \\
\hline 12 & Limonene oxide & 0.16 & 0.37 & 0.37 \\
\hline 13 & Cis-limonen oxide & 0.11 & 0.14 & - \\
\hline 14 & Camphor & 0.11 & - & - \\
\hline 15 & Estragole & 41.09 & 50.65 & 29.30 \\
\hline 16 & 2-Cyclohexen-1-ol,2-methyl-5-(1-methylethenyl)-, cis- & 0.61 & 0.56 & 0.29 \\
\hline 17 & Fenchyl acetate & 0.29 & 0.25 & 0.23 \\
\hline 18 & 2-Cyclohexen-1-one,2-methyl-5-(1-methylethenyl)- (CAS) & - & 2.08 & 1.87 \\
\hline 19 & p-Anisaldehyde & - & - & 0.19 \\
\hline 20 & Anethole & 22.21 & 13.83 & 3.54 \\
\hline 21 & Phenol,4-chloro-5-methyl-2-(1-methylethyl)- (CAS) & - & - & 0.14 \\
\hline 22 & 2-Hydroxy-4-methylacetophenone & 0.18 & - & - \\
\hline 23 & 2-Oxabicyclo[2.2.2]octan-6-ol,1,3,3-trimethyl-, acetate & 0.03 & 0.03 & 0.04 \\
\hline 24 & 6-[18o]-acetyl-7-hydroxy-2,2-dimeth.ylbenzopyran & 0.06 & - & 0.06 \\
\hline 25 & Apiol & 0.11 & - & - \\
\hline 26 & $\alpha$-Cubebene & - & 0.05 & - \\
\hline 27 & Myristicin & - & 0.07 & - \\
\hline 28 & Caryophyllene oxide & - & 0.06 & - \\
\hline 29 & Tricyclo[5.2.2.0(1,6)]undecan-3-ol,2-methylene-6,8,8-trimethyl- & - & 0.09 & - \\
\hline 30 & 6,7-Dimethoxy-3-hydroxybenzopyran-2-one & - & 1.14 & 1.41 \\
\hline 31 & 2-Pentadecanone,6,10,14-trimethyl- & 0.03 & 0.05 & - \\
\hline \multirow[t]{2}{*}{32} & 7-Hydroxy-5,8-dimethoxyflavanone & 0.04 & - & - \\
\hline & Total & 99.82 & 99.91 & 99.96 \\
\hline
\end{tabular}


identified, the main compounds of the essential oil were Estragole, Anethole, Limonene, Fenchone, $\gamma$-Terpinene and $\alpha$-Pinene, which represent from $92.5 \%-95.13 \%$ of fennel oil.

It can be seen from $\left(\mathrm{M}_{1} \mathrm{~F}_{0}\right)$ treatment, the major component was Estragole (50.65 \%), followed by D-Limonene (18.72\%), Anethole $(13.83 \%)$, L-Fenchone $(4.57 \%), \quad \gamma$-Terpinene $(3.12 \%)$ and $\alpha$-Pinene $(1.61 \%)$. Also in, control plants $\left(\mathrm{M}_{0} \mathrm{~F}_{0}\right)$ the major component was Estragole $(41.09 \%)$, followed by Anethole (22.21\%), D-Limonene (14.55\%), L-Fenchone $(11.83 \%), \gamma$-Terpinene $(4.21 \%)$ and $\alpha$-Pinene $(1.24 \%)$. But, when using mycorrhiza plus $75 \%$ of chemical fertilizers, the major component was D-Limonene $(34.58 \%)$ followed by Estragole (29.30\%), L-Fenchone (20.43\%) and Anethole $(3.54 \%), \alpha$-Pinene $(2.71 \%)$ and $\gamma$-Terpinene $(1.25 \%)$.

From the previous results it can be noted that, there was a decrease in Estragole percentage and an increase in Limonene and Fenchone percentages when inoculated fennel plants with mycorrhiza plus $75 \%$ of chemical fertilizers compared with the other two treatments.

The present results are in accordance with the observations of earlier researchers such as Kapoor et al. (2004) on fennel plant, which revealed that, the level of anethole was significantly enhanced on mycorrhization. Karagiannidis et al. (2011) on oregano and mint plants, reported that, the composition of the essential oil in mycorrhizal plants differed from the oil of non-mycorrhizal plants, they also indicate that it may be possible to use mycorrhiza to affect the quality of the essential oil production.

\subsection{Recommendation}

To obtain the best results from the heaviest fruit weight/plant, fruit yield/feddan, oil yield/feddan and minimum level of Estragole content in volatile oil, it is recommended inoculating fennel plants with mycorrhiza plus $75 \%$ of the recommended dose of chemical fertilizers.

\section{REFERENCES}

A. O. A. C. (1970). Official Methods of Analysis of the Association of Official Analytical Chemists. $17^{\text {th }}$ edition. Published by Association of Official Analytical Chemists International, Maryland, U.S. A.

Adams R. P. (2007). Identification of essential oil

$$
\text { components }
$$

by

gas chromatography/mass

spectroscopy.

Allured, Carol Stream, Illinois, USA.

Alireza D. (2012). Effect of chemicals and biofertilizers on yield, growth parameters and essential oil contents of fennel (Foeniculum vulgare, Mill.). J. Med. Plants and By-products, 2: 101-105.

Badawy M. Y. M. (2002). Physiological studies on Foeniculum vulgare, Mill. plant under Sinai conditions. M. Sc., Thesis Fac. Agric., Cairo Univ., Egypt.

British Pharmacopoeia (1963). Determination of Volatile Oil in Drugs. The Pharmaceutical Press. 17 Bloomsburg, Square. W.C.I. London, UK.

Chaplin M. F. and Kennedy J. F. (1994). Carbohydrate Analysis, A practical Approach. Oxford Univ. Press. U. S. A. pp 31-32.

Chapman H. D. and Pratt P. F. (1961). Methods of Soil, Plants and Waters Analysis. University of California, Division of Agricultural Sciences, USA.

Darzi M.T., Ghalavand A., Rejali f. and Sefidkon F. (2007). Effects of biofertilizers application on yield and yield components in fennel (Foeniculum vulgare, Mill.). Iranian J. Med. Arom. Plants, 22, (4) : 276 - 292.

Fatemeh H., Bahram M., Farrokh R., Khoei M. Y. and Alireza T. (2013). Effect of bio and chemical fertilizers on seed yield and its components of dill (Anethum graveolens). J. Med. Plants Res., 7(3): 111-117.

Hach C. C., Brayton S. V. and Nopelove A. B. (1985). A powerful Kjeldahl nitrogen method using peroxy-mono sulfuric acid. J. Agric. Food Chem., 33: 1117-1123.

Karagiannidis N., Thomidis T., Lazari D. and Panou-Filotheouc E. (2011). Effect of three Greek arbuscular mycorrhizal fungi in improving the growth, nutrient concentration, and production of essential oils of oregano and mint plants. Sci. Hort., 129: 329-334.

Kapoor R., Giri B. and Mukerji K.G. (2004). Improved growth and essential oil yield and quality in Foeniculum vulgare, Mill. on mycorrhizal inoculation supplemented with P-fertilizer. Bioresource Tech., 93: 307-311.

Mohammad T. D. (2012). Effect of biofertilizers application on quantitative and qualitative yield of fennel (Foeniculum vulgare) in a 
sustainable production system. Intl. J. Agric. and Crop Sci., 4(4):187-192.

Mohsen N., Mohammad A., Alireza S. and Kabir E. (2014). Effect of phosphorus fertilizer and mycorrhiza on protein percent, dry weight, weight of 1000 grain in wheat. Int. J. Plant, Animal and Environ. Sci., available online at www. ijpaes.com. ISSN 2231-4490.

Paolo Z. and Paulina O. (2008). Effects of mycorrhizal colonization and fertilization on growth and photosynthesis of sweet basil under salt stress. J. Plant Nut., 31 (3): $497-513$.

Snedecor G. W. and Cochran W. G. (1982). Statistical Methods. The Iowa State Univ., Press., Ames., Iowa, U.S.A.

Snell D. S. and Snell C. T. (1949). Calorimetric Methods of Analysis. $3^{\text {rd }}$ Ed. D. Van Nostrand Comp. Inc. New York, London.

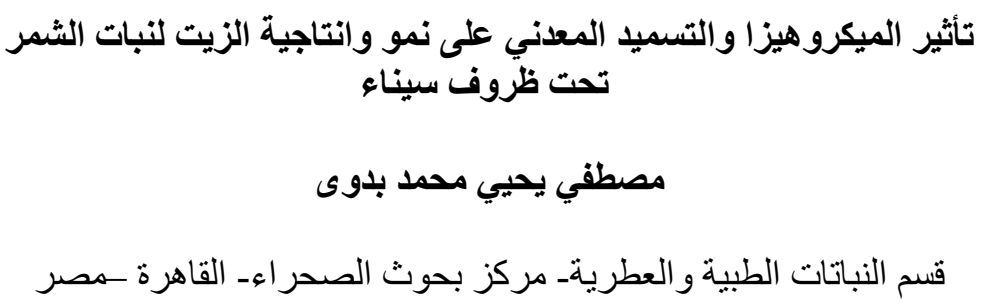

\section{ملخص}

تم اجر اء التجربة بمحطة بحوث المغاره التابعه لمركز بحوث الصحر اء بمحافظة شمال سيناء، وذللك خلال موسمين

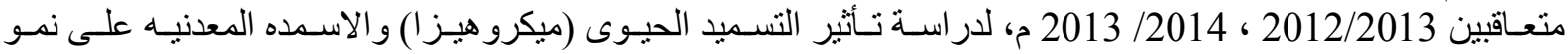

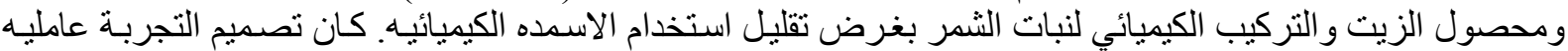

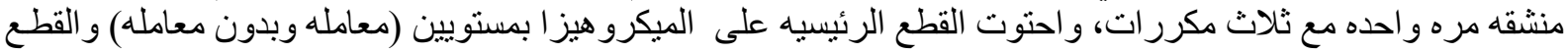

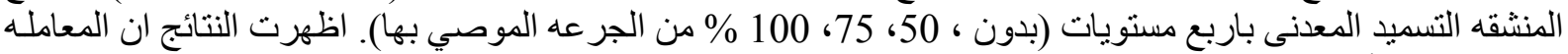

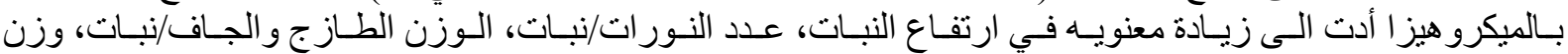

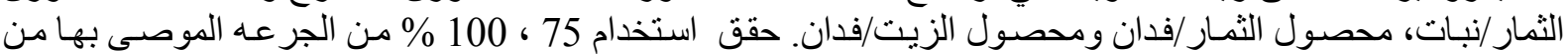

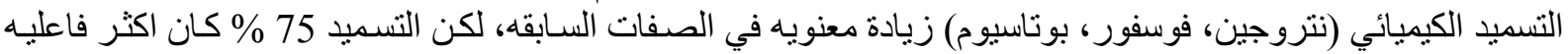

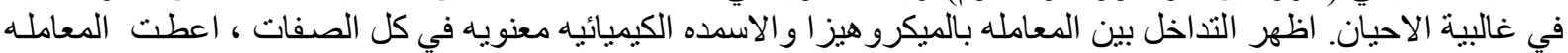

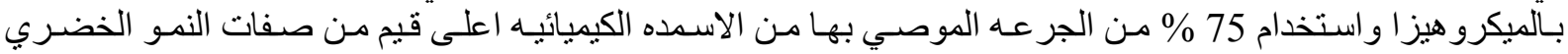

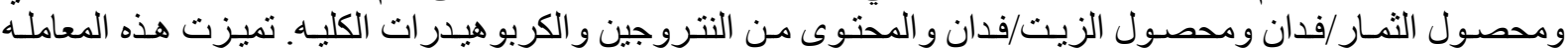

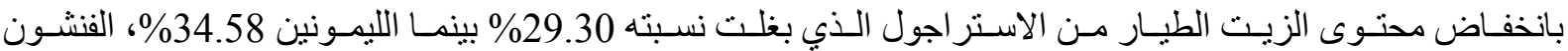

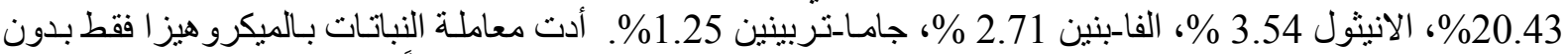

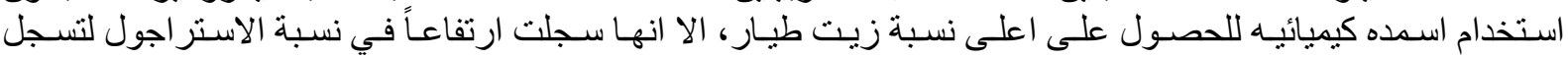

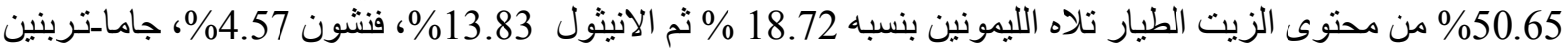

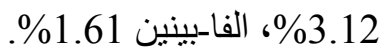

المجلة العلمية لكلية الزراعة جامعة القاهرة ـ المجلد (67) العلد الثالث (يوليو 2016 ) :255-245. 